\title{
Relationship between skin color and some fruit quality characteristics of 'Hass' avocado $^{1,2}$
}

\author{
Jorge A. Osuna-García $a^{2}$, Gilles Doyon ${ }^{3}$, Samuel Salazar-García', \\ Ricardo Goenaga 4 and Isidro J. L. González-Durán ${ }^{2}$
}

J. Agric. Univ. P.R. 95(1-2):15-23 (2011)

\begin{abstract}
Mexico is the main 'Hass' avocado exporter in the world. More than $300,000 t$ are exported every year. The United States of America, Japan, the European Union, and Canada are the main importer countries. Recently, 'Hass' avocado shipments to Canada containing fruit with skin blackening have been rejected since this characteristic is associated with low pulp firmness and short shelf life. The objective of this study was to determine the relationship between skin color of 'Hass' avocado fruit with quality characteristics. Fruit varying in black skin color (from 0 to $100 \%$, categories 1 to 5 ) were collected from two different packinghouses in Michoacán, Mexico. Treatments were arranged in a split-plot design with five replications. Significant differences were detected between packinghouses for weight, length, skin color ('a', 'b', chroma and hue) and pulp firmness but not for width, dry matter content or the Avocado Maturity Index (AMI). As color skin category increased towards more blackened fruit, AMl value increased, firmness decreased but dry matter content did not change. These results provide evidence that fruit skin blackening is not associated with lower fruit quality, but it did lower pulp firmness at fruit packing.
\end{abstract}

Key words: Skin blackening, firmness, dry matter, weight, maturity index

\section{RESUMEN}

Relación entre el color de epidermis y algunas características de calidad en frutos de aguacate 'Hass'

México es el principal exportador de aguacate 'Hass' en el mundo con más de $300,000 \mathrm{t}$ anuales. Los principales importadores son Estados Unidos de América, Japón, la Unión Europea y Canadá. Recientemente,

${ }^{1}$ Manuscript submitted to Editorial Board on 28 October 2010.

${ }^{2}$ INIFAP-Campo Experimental Santiago Ixcuintla, Apartado Postal 100, Santiago Ixcuintla, Nayarit 63300, México. osuna.jorgealberto@inifap.gob.mx

${ }^{3}$ Food Research and Development Centre, Agriculture and Agri-Food Canada, 3600 Casavant Blvd. West, St. Hyacinthe, Quebec, Canada J2S 8E3.

${ }^{4}$ USDA-ARS, Tropical Agriculture Research Station, 2200 P. A. Campos Ave., Suite 201, Mayagüez, Puerto Rico 00680-5470, USA. 


\begin{abstract}
embarques de aguacate 'Hass' que contenían frutos con ennegrecimiento de la epidermis fueron rechazados por el mercado canadiense, ya que esta característica se asocia con baja firmeza de pulpa y corta vida de anaquel. El objetivo de este estudio fue determinar la relación entre el color de la epidermis de frutos de aguacate 'Hass' con algunas características de calidad. En dos empacadoras de Michoacán, México, se tomaron muestras de frutos con diferentes porcentajes de color negro en la epidermis (de 0 a $100 \%$; categorías 1 a 5). A cada fruto se le midió el color externo [luminosidad (L), ' $a$ ', ' $b$ ', croma y ángulo de tono], firmeza de pulpa, contenido de materia seca y el índice de maduración. Se empleó un diseño de parcelas divididas con cinco repeticiones. Se detectaron diferencias significativas entre empacadoras para peso, largo, color de cáscara ('a', ' $b$ ', croma y hue) así como para firmeza de pulpa pero no para ancho, contenido de materia seca ni el índice de maduración. Se observó que conforme el color de categoría se incrementó hacia frutos más obscuros, los valores del índice de madurez se incrementaron, la firmeza disminuyó pero el contenido de materia seca no varió. Estos resultados proveen evidencia de que el obscurecimiento de la cáscara no está asociado con la baja calidad de los frutos, aunque sí con la disminución de la firmeza de pulpa al momento del empacado.
\end{abstract}

Palabras clave: Ennegrecimiento de epidermis, firmeza, materia seca, peso, índice de madurez

\title{
INTRODUCTION
}

Mexico is the main exporter of 'Hass' avocado (Mill) in the world with more than 300,000 t of fruit exported in 2007 (FAOSTAT, 2010). About 90\% of the total avocado production in Mexico occurs in the state of Michoacán (SIACON-SAGARPA, 2010). The main importer countries of Mexican avocado are the United States of America, Japan, the European Union and Canada (Salazar-García et al., 2005). The main harvest season for 'Hass' avocado in Michoacán extends from September until late April. Avocado fruits harvested early in the season often do not reach the minimum dry matter market criteria (i.e., legal maturity) of $21.5 \%$. Lower fruit dry matter is associated with irregular ripening and reduced shelf life. Fruit harvested from mid October to early January reach adequate dry matter (> $21.5 \%$ ) and consequently, ripen properly and have good shelf life. Fruit harvested after mid January attain high dry matter $(>28 \%)$, thus meeting legal maturity standards, but unfortunately fruit also develop blackening of the skin, all of which can confuse customers since the fruit appears to be ripe but is not soft. This color change from green to black results from an initial decrease in chlorophyll content, followed by an increase in the content of the anthocyanin cyaniding 3-O-glucoside (Cox et al., 2004). Unlike other fruit crop species, avocado fruit will not mature and ripen while on the tree but several days after being harvested (Werman and Neeman, 1987), a desired trait as it allows growers to delay harvesting if market prices are not high (Erickson et al., 1970). The longer the fruit remains on the tree, the higher the pulp oil and dry matter contents as 
well as the degree of skin blackening (Hofman et al., 2000; Ozdemir and Topuz, 2004). Late-picked fruit reach maturity faster than fruit harvested at legal maturity (Ranney, 1991). About $80 \%$ of the avocado orchards in Michoacán, Mexico, are located at an altitude ranging between 1,600 to 2,200 $\mathrm{m}$ above sea level, and tree phenology includes four flowering flushes, thus making 'Hass' avocado available almost year-round (Salazar-García, 2000). Recently, 'Hass' avocado shipments to Canada containing fruit with skin blackening have been rejected since this characteristic is associated with low pulp firmness and short shelf life. This situation prompted the authors to conduct the study described herein in order to determine the relationship between skin color of 'Hass' avocado fruit with other quality characteristics, i.e., physical dimensions, dry weight and firmness.

\section{MATERIALS AND METHODS}

The experiment was carried out during January 2006 at two packinghouses herein referred to as Packinghouse 1 and Packinghouse 2, in Uruapan, Michoacán, Mexico. Fruits weighing $262 \pm 36 \mathrm{~g}$ varying in skin color (five fruits for each category) were collected from both packinghouses. The following scale was used to establish skin color categories according to the area blackened: $1=$ fully green skin; $2=\leq 25 \%$ skin blackening; $3=26$ to $50 \%$ skin blackening; $4=51$ to $75 \%$ skin blackening; $5=>75 \%$ skin blackening. Weight, length and width of fruit from each packinghouse were determined. Skin color was measured with a portable Hunter MiniScan XE Plus colorimeter, Model 45/O-S (Hunter Associates Lab, Reston, VA, USA) ${ }^{5}$ and the results were expressed in accordance with the CIELAB system with reference to CIE $10^{\circ}$ Standard observer and CIE Standard Illuminant D65. The measurements were performed through a 5-mm diameter diaphragm with an optical glass. Calibration of the device was done with black and white standard tiles. The parameters determined were Lightness $[\mathrm{L}=0$ (black) and $\mathrm{L}=$ 100 (white)], 'a', and 'b'. Negative 'a' indicates greenness whereas positive ' $a$ ' means redness. Negative ' $b$ ' indicates blueness whereas positive 'b' means yellowness. Chroma and hue were calculated from ' $a$ ' and 'b'. Chroma $\left[\left(a^{2}+b^{2}\right)^{1 / 2}\right]$ is the saturation or vividness of color whereas hue angle (arctangent b/a) is the basic unit of color (McGuire, 1992); and it can be interpreted as follows: $0^{\circ}=$ red; $90^{\circ}=$ yellow; $180^{\circ}=$ bluish-green; and $270^{\circ}=$ blue. In addition, the Avocado Maturity Index (AMI) was

\footnotetext{
${ }^{5}$ Company or trade names in this publication are used only to provide specific information. Mention of a company or trade name does not constitute a warranty of equipment or materials by the Agricultural Experiment Station of the University of Puerto Rico, nor is this mention a statement of preference over other equipment or materials.
} 
calculated according to Francis and Clydesdale (1975) with the following adapted formula: AMI $=( \pm \mathrm{a} / \mathrm{L}) \times(1)(1000) /\left[\left(\mathrm{a}^{2}+\mathrm{b}^{2}\right)^{1 / 2}\right]$. Firmness was measured by using a DFE-050 Chatillon penetrometer (Ametek Instruments, Largo, FL, USA) with a 10-mm diameter head. A portion of the skin of approximately $5 \mathrm{~mm}$ was removed in the equatorial region of each fruit to expose the pulp, and the probe was inserted at about 4-mm depth at a speed of $180 \mathrm{~mm} / \mathrm{min}$. Firmness was expressed in Newtons (N). Dry matter was determined by cutting $10 \mathrm{~g}$ of pulp in thin slices with a potato peeler, placing slices in glass Petri dishes and drying them in a microwave oven for 6 to 10 min until constant weight (Lee and Coggins, 1982). The percentage dry matter content was calculated as [(dry weight $) /($ fresh weight $) \times 100]$.

The experimental design consisted of a split-plot design with five replications. Main plots were packinghouses, and subplots were skin color categories. Analysis of variance was conducted by using the PROC ANOVA procedure of SAS (Release 9.1 for Windows, SAS Institute, Cary, NC, 1998). Correlation coefficients were determined by using PROC CORR. Means separation was performed with the WallerDuncan procedure at $\mathrm{P} \geq 0.05$.

\section{RESULTS AND DISCUSSION}

The significance for the experimental variables used to evaluate the relationship between skin color and fruit characteristics is presented in Table 1 . It was observed that most of the variables were not significant $(P \geq 0.05)$ for the interaction. However, 'b' and hue skin color as well as pulp firmness showed significant difference for the interaction.

Significant differences $(\mathrm{P} \leq 0.05)$ between packinghouses were detected for weight, length, 'a', 'b', chroma, hue skin color, and firmness whereas width, lightness, dry matter content (DM), and the Avocado Maturity Index (AMI) did not show any significant difference (Table 2). Fruits collected from packinghouse 2 were heavier and longer than those from packinghouse 1 . In fact, according to the $016 \mathrm{Mexi}-$ can Norm for quality standards of 'Hass' avocado (UDECAM, 2002), the fruit from packinghouse 2 belongs to a 'super extra' size ( $>266 \mathrm{~g}$ ) whereas fruit from packinghouse 1 had an 'extra' size (211 to $265 \mathrm{~g}$ ), with fruit from packinghouse 2 being of higher quality. Concerning skin color, fruit from both packinghouses did not show any significant difference for lightness averaging 24.6 for packinghouse 1 and 22.7 for packinghouse 2 . These low values indicate darkness of the skin, something expected because most of the fruit had more than $25 \%$ of blackened skin. However, fruit of packinghouse 2 showed a greener skin as indicated by a lower ' $a$ ', higher ' $b$ ' and 'H' values, and a more 
TABLE 1. - Significance for experimental variables used to evaluate the relationship between shin color and fruit quality characteristics of 'Hass' avocado in fruit from two packinghouses in Michoacán, Mexico.

\begin{tabular}{|c|c|c|c|c|c|c|c|c|c|c|c|}
\hline \multirow[b]{2}{*}{ Source } & \multirow[b]{2}{*}{$\begin{array}{c}\text { Fruit } \\
\text { Weight }\end{array}$} & \multirow{2}{*}{$\begin{array}{l}\text { Fruit } \\
\text { Length }\end{array}$} & \multirow{2}{*}{$\begin{array}{l}\text { Fruit } \\
\text { Width }\end{array}$} & \multicolumn{5}{|c|}{ Skin Color } & \multirow[b]{2}{*}{ Firmness } & \multirow[b]{2}{*}{$\mathrm{DM}^{4}$} & \multirow[b]{2}{*}{$\mathrm{AMI}^{5}$} \\
\hline & & & & $\mathrm{L}^{1}$ & a & $\mathrm{b}$ & $\mathrm{C}^{2}$ & $\mathrm{H}^{3}$ & & & \\
\hline Packinghouse (PH) & $*$ & 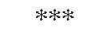 & ns & ns & * & * & *** & $* * *$ & $* * *$ & $\mathrm{~ns}$ & $\mathrm{~ns}$ \\
\hline Category (C) & ns & ns & ns & $* * *$ & $* * *$ & $* * *$ & $* * *$ & $*$ & $* * *$ & $*$ & $* * *$ \\
\hline $\mathrm{PH} \times \mathrm{C}$ & ns & ns & ns & ns & ns & $*$ & ns & $*$ & $* * *$ & ns & ns \\
\hline
\end{tabular}

$*$ Significant $(\mathrm{P} \leq 0.05) ; * *$ Significant $(\mathrm{P} \leq 0.01) ; * * *=$ Significant $(\mathrm{P} \leq 0.001)$; $\mathrm{ns}=$ not significant $\alpha=0.05$ level

${ }^{1}$ Lightness, ${ }^{2} \mathrm{Chroma},{ }^{3} \mathrm{Hue},{ }^{4}$ Dry Matter Content, ${ }^{5}$ Avocado Maturity Index.

TABLE 2.-Relationship of packinghouse on fruit weight, length, width, skin color, firmness, dry matter content (DM), Avocado Maturity Index (AMI) in fruit from two packinghouses in Michoacán, Mexico.

\begin{tabular}{|c|c|c|c|c|c|c|c|c|c|c|c|}
\hline \multirow{2}{*}{$\begin{array}{l}\text { Packing } \\
\text { house }\end{array}$} & \multirow{2}{*}{$\begin{array}{c}\text { Fruit } \\
\text { Weight (g) }\end{array}$} & \multirow{2}{*}{\multicolumn{2}{|c|}{$\begin{array}{l}\text { Fruit Length Fruit Width } \\
(\mathrm{cm}) \quad(\mathrm{cm})\end{array}$}} & \multicolumn{5}{|c|}{ Skin Color } & \multirow{2}{*}{$\begin{array}{l}\text { Firmness } \\
(\mathrm{N})\end{array}$} & \multirow[b]{2}{*}{$\mathrm{DM}^{4}(\%)$} & \multirow[b]{2}{*}{$\mathrm{AMI}^{5}$} \\
\hline & & & & $\mathrm{L}^{1}$ & $a$ & $\mathrm{~b}$ & $\mathrm{C}^{2}$ & $\mathrm{H}^{3}$ & & & \\
\hline $\mathbf{1}$ & $\begin{array}{l}249.3 \pm 8.1 \mathrm{~b} \\
274.5 \pm 5.2 \mathrm{a}\end{array}$ & $\begin{array}{r}9.7 \pm 0.2 \mathrm{~b} \\
10.8 \pm 0.2 \mathrm{a}\end{array}$ & $\begin{array}{l}7.1 \pm 0.1 \mathrm{a} \\
7.2 \pm 0.1 \mathrm{a}\end{array}$ & $\begin{array}{l}24.6 \pm 1.0 \mathrm{a} \\
22.7 \pm 1.2 \mathrm{a}\end{array}$ & $\begin{array}{l}-2.3 \pm 0.5 a \\
-3.7 \pm 0.8 b\end{array}$ & $\begin{array}{c}8.4 \pm 0.9 \mathrm{~b} \\
12.1 \pm 1.8 \mathrm{a}\end{array}$ & $\begin{array}{l}8.9 \pm 1.0 \mathrm{~b} \\
13.0 \pm 1.9 \mathrm{a}\end{array}$ & $\begin{array}{l}75.7 \pm 1.9 \mathrm{a} \\
67.6 \pm 1.3 \mathrm{~b}\end{array}$ & $\begin{array}{l}246.3 \pm 3.5 \mathrm{a} \\
220.7 \pm 6.1 \mathrm{~b}\end{array}$ & $\begin{array}{l}36.0 \pm 1.0 \mathrm{a} \\
36.2 \pm 0.6 \mathrm{a}\end{array}$ & $\begin{array}{l}-5.5 \pm 2.0 \mathrm{a} \\
-5.7 \pm 3.9 \mathrm{a}\end{array}$ \\
\hline
\end{tabular}

Values with the same letters in a column are not significantly different using the Waller-Duncan procedure, $P \geq 0.05$. Means of 25 observations \pm Standard Error. ${ }^{1}$ Lightness, ${ }^{2} \mathrm{Chroma},{ }^{3} \mathrm{Hue},{ }^{4}$ Dry Matter Content, ${ }^{5}$ Avocado Maturity Index. 
TABLE 3.-Relationship of skin color categories on weight, length, width, skin color, firmness, dry matter content (DM), Avocado Maturity Index (AMI) in fruit having different skin color categories in Michoacán, Mexico.

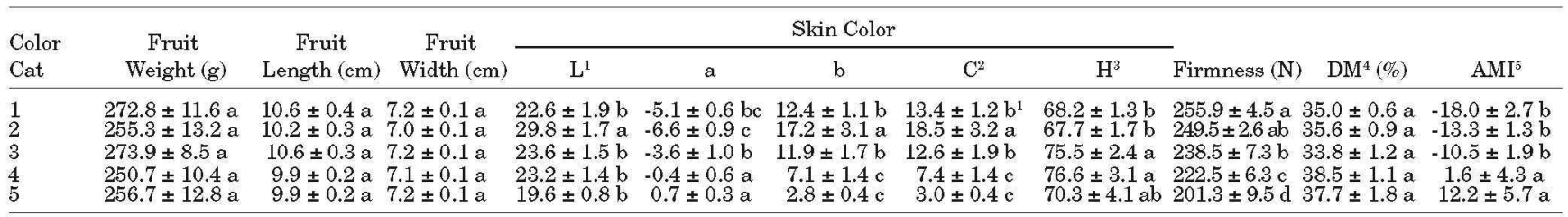

Values with the same letters in a column are not significantly different using the Waller-Duncan procedure, $\mathrm{P} \geq 0.05$. Means of 10 observations \pm Standard Error. ${ }^{1}$ Lightness, ${ }^{2}$ Chroma, ${ }^{3}$ Hue, ${ }^{4}$ Dry Matter Content, ${ }^{5}$ Avocado Maturity Index. 
vivid color (higher ' $\mathrm{C}$ ') than those of packinghouse 1. Fruit of packinghouse 1 showed significantly higher firmness ( $246.3 \mathrm{~N}$ ) than fruit of packinghouse $2(220.7 \mathrm{~N})$. This difference could be the result of fruit from packinghouse 1 being tested one day after harvest whereas those from packinghouse 2 were tested 36 to $48 \mathrm{~h}$ after harvest. It is a common practice to harvest fruit during the whole day, with some arriving at the packinghouse in the afternoon for packing the next day. However, when the fruit volume is very high, the packinghouse requires an additional day for packing. Under this scenario, storage of fruit is done at room temperature $\left(24 \pm 4{ }^{\circ} \mathrm{C} ; 75 \pm 10 \%\right.$ $\mathrm{RH})$ all of which may cause some softening of the fruit. There were no significant differences in fruit dry matter content between packinghouses. Fruit from both packinghouses had a dry matter content of $36 \%$ which greatly surpasses the legal maturity $(21.5 \%)$ needed for fruit harvest (Salazar-García et al., 2005). No significant differences between packinghouses were found for AMI, thus indicating that the fruit from both packinghouses were at a similar ripening stage.

Fruit of different skin color categories were very similar among themselves since no significant differences were detected for fruit weight, length, width, and DM content. However, significant differences were detected for skin color (lightness, 'a', 'b', chroma and hue), as well as for firmness and AMI (Table 3). Fruit having higher skin color categories ( 4 and $5 ;>51 \%$ of the skin area blackened) showed ' $a$ ' values closer to zero, all of which means less greener fruit than those having more negative ' $a$ ' values. The 'b' values were smaller for these two color categories, thus indicating that they had less yellow color. Fruit in these two categories also showed very low chroma values, indicating that the skin color was duller than that of fruit from other categories. As the percentage of blackened skin increased, the pulp firmness decreased and the AMI increased.

Although skin color categories (visual ones) did not have a significant effect on fruit dry matter content, a significant $(P \leq 0.01)$ correlation among lightness, ' $a$ ', 'b', chroma, and AMI was detected with fruit firmness (Table 4 ). This response provides evidence that fruit skin blackening was associated only with a reduction in pulp firmness. All of the variables, except hue, had a high $(>0.40)$ and significant $(\mathrm{P} \leq 0.01)$ correlation with pulp firmness whereas none of them were significantly correlated with DM content. In this study the effect of storage on avocado fruit of various skin color categories was not determined. Currently, the effect of skin color categories, and hence fruit blackening, on 'Hass' avocado fruit shelf life is under study. 
TABLE 4.-Correlation between skin color ( $L, a, C, H u e)$ and Avocado Maturity Index (AMI) with Firmness and Dry Matter Content. Pearson's Correlation Coefficient $N=50$.

\begin{tabular}{llcccccc}
\hline & & \multicolumn{7}{c}{ Skin Color } & \\
\cline { 3 - 7 } Variable & & Lightness & $\mathrm{a}$ & $\mathrm{b}$ & Chroma & Hue & AMI \\
\hline Firmness & $r$ & 0.41522 & -0.45579 & 0.40685 & 0.40523 & 0.19236 & -0.49127 \\
& $P$ & 0.0027 & 0.0009 & 0.0034 & 0.0035 & 0.1808 & 0.0003 \\
& & $*$ & $* * *$ & $* *$ & $* *$ & $\mathrm{~ns}$ & $* * *$ \\
Dry Matter & $r$ & 0.19485 & 0.09142 & -0.06251 & -0.06006 & -0.14985 & 0.16474 \\
& $P$ & 0.1751 & 0.5278 & 0.6661 & 0.6787 & 0.2990 & 0.2529 \\
& & ns & ns & ns & ns & ns & ns \\
\hline
\end{tabular}

$r=$ correlation coefficient; $\mathrm{P}=$ probability; * = Significant $(\mathrm{P} \leq 0.05) ; * *=$ Significant $(\mathrm{P} \leq 0.01) ; *^{* * *}=$ Significant $(P \leq 0.001) ; \mathrm{ns}=$ not significant $\alpha=0.05$ level.

The relationship among skin color categories with firmness and AMI is illustrated in Figure 1. As the color skin category increased, the AMI or maturity stage of the fruit increased, and consequently the

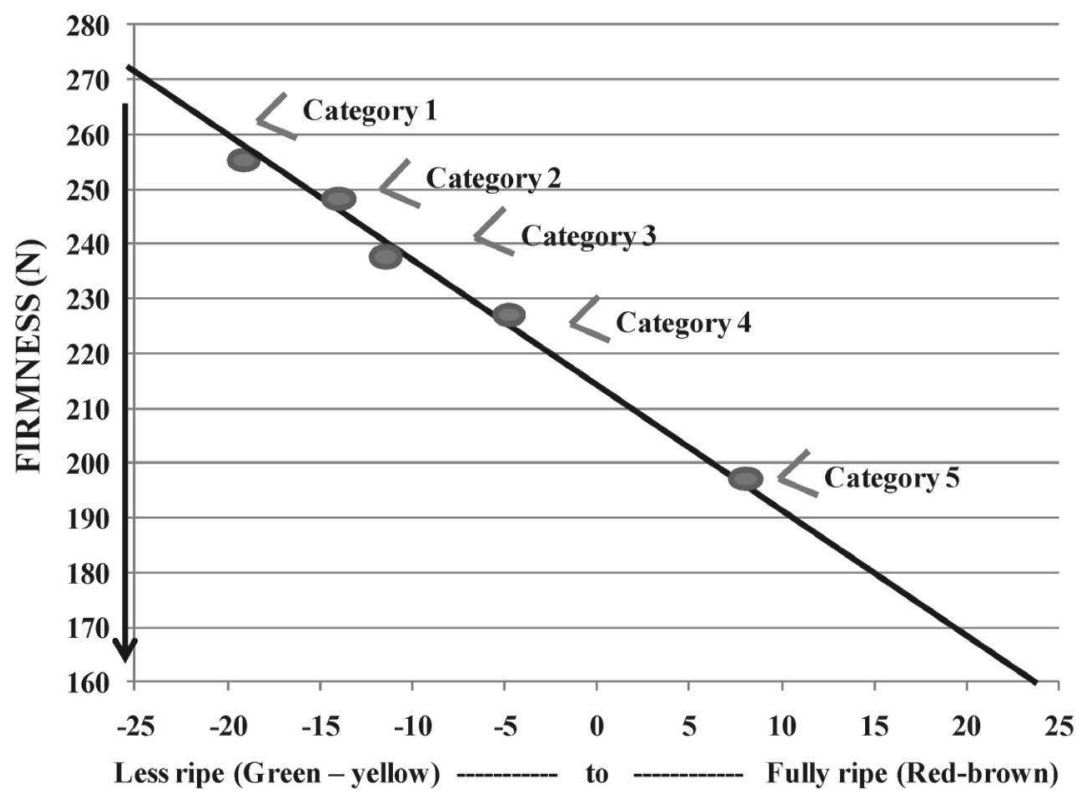

\section{AVOCADO MATURITY INDEX}

FIGURE 1. Relationship of color skin categories with Avocado Maturity Index (AMI) and pulp firmness. 
pulp firmness decreased. The relationship was adjusted to create a linear model where $\mathrm{Y}=\mathrm{a}-\mathrm{bx}$, where $\mathrm{Y}=$ Firmness $(\mathrm{N}) ; \mathrm{x}=\mathrm{AMI} ; \mathrm{R}^{2}=$ $0.988 ; \mathrm{a}=223.6 \mathrm{~N} ;-\mathrm{b}=-1.78 \mathrm{~N} /$ AMI Units.

\section{CONCLUSIONS}

Significant differences were detected between packinghouses for weight, length, skin color ('a', 'b', chroma and hue) and pulp firmness but not for width, dry matter content or the Avocado Maturity Index (AMI). As color skin category increased towards more blackened fruit, AMI value increased, firmness decreased but dry matter content did not change. These results provide evidence that fruit skin blackening is not associated with lower fruit quality but it did provide evidence of lower pulp firmness at fruit packing.

\section{LITERATURE CITED}

Cox, K. A., T. K. McGhie, A. White and A. B. Woolf, 2004. Skin colour and pigment changes during ripening of 'Hass' avocado fruit. Postharvest Biology and Technology 31:287-294.

Erickson, L. C., J. L. Eaks and G. G. Porter, 1970. Over-maturity in 'Hass' avocados. Calif. Avocado Soc. Yrbk. 54:62-65.

FAOSTAT, 2010. FAOSTAT DATABASE. http://faostat.fao.org. Consulted in August, 2011.

Francis, F. J. and F. M. Clydesdale, 1975. Food colorimetry: Theory and Applications. The AVI Publishing Company, Inc., Wesport, Conn.

Hofman, P. J., M. Jobin-Décor and J. Giles, 2000. Percentage of dry matter and oil content are not reliable indicators of fruit maturity or quality in late-harvested 'Hass' avocado. HortScience 35:694-695.

Lee, S. K. and C. W. Coggins, 1982. Dry weight method for determination of avocado fruit maturity. Calif. Avocado Soc. Yrbk. 66:67-70

McGuire, R. G., 1992. Reporting of Objective Color Measurement. HortScience 27:1254-1255.

Ozdemir, F. and A. Topuz, 2004. Changes in dry matter, oil content and fatty acids composition of avocado during harvesting time and post-harvesting ripening period. Food Chemistry 86:79-83.

Ranney, C., 1991. Relationship between physiological maturity and percent dry matter of avocados. Calif. Avocado Soc. Yrbl. 75:71-85.

Salazar-García, S., 2000. Fisiología reproductiva del aguacate. pp. 57-83. In: Téliz, D. (Ed.). El Aguacate y su Manejo Integrado. Ediciones Mundi-Prensa, México.

Salazar-García, S., L. Zamora-Cuevas and R. J. Vega-López, 2005. Update on the avocado industry of Michoacán, México. Calif. Avocado Soc. Yrbk. 87:31-44.

SAS, 1998. SAS User's Guide: Statistics. Version 9. SAS Inst., Cary, N.C. USA

SIACON-SAGARPA, 2010. http://www.siap-sagarpa.gob.mx. Consulted in August, 2011.

UDECAM, 2002. Unión de Empacadores y Comercializadores de Aguacate de Michoacán, A.C. Norma NMX-016-FF-2002-SCFI. Referente a los Estándares de Calidad para la Comercialización del Aguacate 'Hass'. 6p.

Werman, M. J. and I. Neeman, 1987. Avocado oil production and chemical characteristics. Journal of the American Oil Chemists' Society 64(2):229-232. 
